Journal of Finance Research

\title{
Research on Tax Planning of PPP Projects in China: Based on the Perspective of Digital Economy
}

\section{Jiangyu Huang* Kezhen Liu}

College of Big Data Application and Economics, Guizhou University of Finance and Economics, Guiyang, Guizhou, 550025, China

\begin{tabular}{l} 
ARTICLE INFO \\
\hline Article history \\
Received: 1 October 2020 \\
Revised: 6 October 2020 \\
Accepted: 9 October 2020 \\
Published Online: 16 October 2020 \\
\hline Keywords: \\
PPP project \\
Tax planning \\
Tax risk \\
Digital economy
\end{tabular}

\section{Introduction}

$\mathrm{T}$ he great development of the digital economy requires the full and in-depth participation of diverse organizations such as governments, enterprises, and individuals. The sustainable development of the digital economy requires a good fit between an active government and an effective market. Public Private Partnership (PPP Model) is an important governance tool in the development of the digital economy,

\begin{abstract}
The digital economy has become an important driving force for the growth of fiscal revenue in various countries. Tax planning is essential for the cost accounting of PPP projects, reducing corporate tax burdens, and increasing company value. This paper adopts a case analysis method, taking the smart highway PPP project in Guizhou Province as an example. Through statistical analysis, it is found that the value-for-money and big data of the PPP project affects tax planning, the project's value-added tax input and output items have time mismatches, and enterprises Income tax payment imbalance. In the context of the digital economy, the tax planning of China's PPP projects can be further improved: digital transformation and big data to prevent tax risks caused by value for money evaluation; based on digital technology to improve the value-added tax deduction chain, and digital communication platforms to alleviate time mismatch of value-added tax; use big data to monitor and balance project portfolio investment; improve the level of digital skills of financial personnel.
\end{abstract}

reflecting that public finance is an important pillar of national governance. China began to promote the PPP model in the 1980 s, which played an important role in the development of China's urbanization, sustainable poverty reduction, and efficient provision of public services. According to data from the PPP project database of the Ministry of Finance of China, as of May 2020, there are a total of 9,459 projects in the PPP project management database, with an investment of 14.4 trillion yuan. In the context of the digital economy, China

\footnotetext{
*Corresponding Author:

Jiangyu Huang,

College of Big Data Application and Economics, Guizhou University of Finance and Economics, Guiyang, Guizhou, 550025, China; E-mail:1136591236@qq.com.

Fund Project:

This paper is based on a research project financially supported by "Research on Cultivation of Big Data Thinking and Application Ability of University Undergraduates: Based on the Perspective of Digital Economy (GZJG20200203)", and supported by Guizhou University of Finance and Economics "Teaching Quality and Teaching Reform Project (2019)", entitled "Research on Teaching Reform of Property Insurance Courses under the Background of Big Data (2019JGZZC07)", and supported by "Research on Legal Risks of Multinational Financial Leasing: Based on the 'One Belt One Road'Initiative (HB19FX022)'.
} 
advocates new infrastructure construction and service orientation. The government uses big data, digital transformation, and information technology to promote the intelligentization of public services in underdeveloped areas and enhance citizens' sense of access to public services. The PPP model has the advantages of making up for the government's insufficient funds for public infrastructure construction, overcoming the inefficiency of the government's self-providing public goods, and effectively guiding enterprises to participate in the supply of public services ${ }^{[1]}$.

The combination of the digital economy and the PPP model provides new requirements and development opportunities for China's fiscal and taxation system reform, modern corporate governance model, and smart public service supply. The development of the digital economy highlights the shortcomings of China's current fiscal and taxation systems and practices, which are reflected in the insufficient systemization of fiscal and taxation policies in the PPP model; the legal policies and practices of taxation planning for PPP projects are still in the exploratory stage. In response to the above problems, this research takes the digital economy as the perspective, based on the theory of tax fairness and efficiency balance, and adopts a case study method to analyze the tax planning problems and risks of China's PPP model.

\section{Literature Review}

The PPP model is a long-term cooperative relationship established by the government and enterprises. A partnership is to clarify the rights and obligations of parties through signing a contract. The project is based on a payment mechanism to stimulate the advantages of participants and provide public services to the public in a sustainable and stable manner. The PPP model enables the government to focus on core regulatory and policy-making functions through procurement. Cooperative enterprises give full play to their management and financing advantages to provide citizens with higher-quality public services in a manner consistent with market laws. The effective implementation of the PPP model enables the government, enterprises and citizens to achieve a win-win cooperation. Tax planning refers to taxation activities in which taxpayers must comply with tax laws and regulations, and through reasonable plans, enable taxpayers to achieve the goal of saving taxes, deferring taxes, reducing tax risks, and maximizing tax benefits, while maximizing corporate after-tax profits.

Scholars have conducted research on digital economy, PPP projects and tax planning. Studies have fo- cused on the impact of public-private partnerships in the development of urbanization in the United States on taxation, and emphasized the importance of tax planning in PPP projects ${ }^{[2]}$. Public-private partnerships emphasize the structural compatibility of partner organizations, and should attach importance to effective communication between enterprises, schools, and individuals $^{[3]}$. Tax cuts for public-private partnership (PPP) projects are conducive to reducing the cost of enterprises and increasing the value of the project. National legislation is of great significance to the formation of partners ${ }^{[4]}$. In the development of the digital economy, it is necessary to clarify the relationship between taxation theory and public economics, and pay attention to government expenditures and redistribution taxes in the supply of public products ${ }^{[5]}$. The government builds a partnership for community protection and management of natural resources, which is conducive to enhancing the country's competitiveness ${ }^{[6]}$. Based on the public-private partnership model of the Russian natural resources sector, studies have found that the government should provide tax incentives for investors in infrastructure development and implementing environmental measures ${ }^{[7]}$. The use of digital technology in tax planning is of great significance. Studies have used specialized data sets and executive compensation information to examine the relationship between tax directors, effective tax rates, tax gaps, and taxation measures ${ }^{[8]}$. Studies have analyzed the tax effect of financing in PPP projects ${ }^{[9]}$. Government taxation policies should be conducive to public-private partnership tax-paying enterprises to achieve value for money ${ }^{[10]}$. The design of the communication technology platform for government information is of great significance to the development of the digital economy. The PPP model aims to establish a sustainable online system to reform property tax collection methods and data collection management ${ }^{[11]}$. Scholars analyzed the legal and financing issues of Slovakia and other EU members from 2006 to 2014, and explained the importance of PPP project financing for tax planning ${ }^{[12]}$. The article reviews the background and important perspectives of infrastructure, public project partnerships, and tax development ${ }^{[13]}$. Scholars analyze public-private investment partnerships based on efficiency estimation methods, which have important implications for the efficiency of tax planning ${ }^{[14]}$. Studies have been conducted on corporate income tax incentives for PPP projects to assess the compatibility of income tax and investment law ${ }^{[15]}$. Based on the analysis of tax policy optimization of the PPP model, the study found that China currently has no specific tax policies 
or guidelines for PPP. Researchers put forward suggestions for optimizing tax planning for the PPP model: China should formulate targeted taxation rules based on the particularity of the PPP model; the government should formulate taxation practice guidelines for the PPP model; tax planning policies should give full play to the advantages of the government and enterprises, and promote Service quality and efficiency ${ }^{[16]}$.

In summary, current research focuses on the importance of PPP projects to achieve value for money in public services, and the lack of tax planning policies in PPP projects. It rarely combines specific cases to discuss the status quo, problems and specific responses of PPP project tax planning in the digital economy. This research focuses on academic and practical problems, and has important value and innovation.

\section{Risk Analysis of Tax Planning in Intelli- gent Highway PPP Project}

\subsection{Reason Analysis of Case Selection}

According to the project database of the Ministry of Finance of China, among the national demonstration PPP projects in Guizhou Province, transportation projects and investment finance account for the largest proportion. On the one hand, Guizhou Province is an important transportation hub in the southwest region, with abundant resources and significant transportation development; on the other hand, Guizhou Province is in a large-scale development stage and there are shortcomings in transportation infrastructure. The transportation PPP project is to make up for the shortcomings of public services. Transportation PPP projects reflect the development needs of China and Guizhou Province, and are of great significance to promote the economic development of China's underdeveloped regions. The combination of transportation and digital economy is in-depth and common, and smart transportation PPP projects are representative, which has important reference value for discussing tax planning issues in PPP projects.

Guizhou Intelligent Expressway PPP project has a large investment amount and the cycle is as long as 30 years. The project reflects the innovation requirements of the digital economy in the construction and operation stages, and has strong demonstration significance and promotion value. The intelligent highway PPP project in Guizhou Province aims to make up for the shortcomings of transportation services, monitor transportation operations and revenue through digital and intelligent technologies, and improve transportation efficiency and people's travel convenience. Smart transportation projects generally adopt the payment method of Viability Gap Funding. When users are not paying enough, the government will provide subsidies to ensure the continuous income and operation of the project company. The government monitors the operation and income changes of transportation projects through digital technology, which can maximize the value of the project. In the operation of the intelligent highway PPP project in Guizhou Province, digital technology will feed back the operation period of the transportation project to the government department, and the government will promptly provide subsidies and supervision based on the revenue and tax data of the transportation project. The transportation PPP project company uses big data technology to track the operation of vehicles throughout the full life cycle, cooperates with the transportation department to deal with traffic conditions and accidents, and effectively adjusts tolls. The tax planning of the smart highway PPP project in Guizhou Province involves project procurement, construction, operation, and handover stages, reflecting the full life cycle of the project, and providing a representative and high-value sample for tax planning.

\subsection{Risk Analysis of Tax Planning for Intelligent Transportation PPP Project}

\subsubsection{The lack of Big Data for Value-For-Money Evaluation Will Reduce the Effectiveness of Tax Planning}

The government adopts the PPP model to provide public transportation services. The essential reason is that the PPP model can achieve better value for money. The value for money of a PPP project should be reflected in the entire life cycle of the project, including qualitative analysis and quantitative evaluation. Due to the lack of data samples, PPP projects mainly focus on qualitative of value for money. The general consensus between academics and practice is that only the quantitative evaluation of projects based on big data can truly reflect value for money. Value-for-money evaluation is currently dominated by the government. Cooperative enterprises mainly refer to the qualitative evaluation results of value-for-money provided by the government. The enterprise has little influence on the project evaluation process. In terms of project tax planning, the PPP project company's taxation behavior is based on changes in the project's market value. Without big data to support value for money, it is difficult to evaluate the operational valuation of PPP projects. In the project 
procurement stage, the government may overestimate the value of the highway project concession rights, and the company will pay extra money for obtaining the concession rights, making the tax planning of the project deviate from the real situation. In order to reduce the pressure on taxes and fees, enterprises may adopt non-compliant methods to avoid taxation, which will eventually lead to tax losses and affect fiscal revenue. The lack of big data for value for money will affect the tax planning and effectiveness of PPP projects.

\subsubsection{Mismatch in the Input and Output Tax Time of the Project's Value-Added Tax}

In the early stage of the intelligent transportation PPP project, there are many infrastructure construction tasks, and a large number of contracts need to be signed with other construction units or cargo providers. The project company's purchase of engineering, goods, and labor services will generate a large amount of input value-added tax (VAT), and the project company's book accounting has a relatively large input allowance. During the construction period of the project, the project company has invested heavily in construction, and its external sales amount is very small. The project company's output tax usually needs to be deducted several years after the operation period, and this process has a large time span. Input VAT cannot be deducted during the construction period, which brings huge financial pressure to enterprises. The input and output VAT in PPP projects have a prominent time mismatch problem. This requires the PPP project company to make tax planning arrangements in advance to prevent the company from facing the risk of paying the output VAT in full. In addition, during the project operation stage, the company' $s$ main source of income is closely related to the government's feasibility gap subsidies and user fees, which also requires tax planning arrangements.

\subsubsection{Imbalance of Corporate Income Tax Pay- ment at Different Project Stages}

The construction period of PPP projects is relatively short, usually 2-3 years, and the operation period is long, usually $8-28$ years. The initial investment cost of the project is too large, and it can only obtain stable income year by year through long-term operation, and it is difficult for enterprises to make up for the huge deficit through short-term operation. The operational characteristics of PPP projects have led to losses in the early stage of operation. As an independent legal person, the PPP SPV cannot use the profits of other projects of the group to reduce losses, which will increase the corporate income tax burden and increase the cost of capital occupation. According to the "Enterprise Income Tax Law of the People's Republic of China", "Losses incurred in the tax year of an enterprise may be carried forward to subsequent years, but the carry-forward period shall not exceed five years." If the PPP project company's losses have not been fully compensated after 5 years, then the profits and losses will not be offset in subsequent years, which will increase the income tax burden of the entire project cycle. Through bank financing, the tax treatment of loan interest capitalization affects the company's tax payment. Tax planning involves the inclusion of loans in financial expenses or construction in progress, or deductions based on actual conditions.

\subsubsection{The Time Value Affects the Changes of Tax Base}

The time span of a PPP project lasts for 10-30 years, and companies must fully consider the time value cost when making long-term investment decisions. Due to the expansion of generalization, bank loan interest, and market changes, companies must consider the time value of funds when making tax planning. The company's financial indicators continue to change with the project operation time, and transactions between the company and its stakeholders will be affected, which will have a direct impact on the tax planning of PPP projects. Project transaction time, transaction payment method and future cash flow status are important factors that affect the company's actual tax burden. The timing of tax payment has led to changes in the results of tax planning, which requires companies to make reasonable capital accounting arrangements to cope with financial pressures.

\subsubsection{Risks of Tax Policy Changes Related to PPP Projects}

The rapid development of the intelligent transportation PPP project provides an important opportunity for the domestic economic cycle and brings new momentum to the innovation and development of enterprises. To promote the development of the market economy, the government usually introduces appropriate tax policies. Taxation plays an important role in regulating macroeconomic development and micro enterprise entities. For PPP project companies, the adjustment of tax policy will bring uncertainty to tax planning and increase the 
difficulty of corporate tax planning. The adjustment of the VAT rate, the costs and financial indicators related to the VAT of the intelligent transportation PPP project company have all changed, which requires timely adjustment of financial statements and revision of tax planning plans. In the context of the digital economy, tax policy changes will accelerate. PPP projects should pay attention to preventing tax policy risks and responding to new requirements of the digital economy.

\section{Conclusion and Research Recommenda- tions}

Based on the analysis of tax planning cases for intelligent transportation PPP projects, the study found that China needs to improve the value-for-money big data, VAT deductions, corporate income tax, and digital capabilities.

\subsection{Prevent the Negative Impact of Value-for- Money Evaluation through Digital Transforma- tion of Professional Agencies}

China is vigorously building big data for government affairs, which is conducive to solving the digital divide between government departments and the accumulation of big data for PPP projects. The quantitative evaluation of value-for-money of PPP projects is inseparable from big data technology and big data applications. Professional big data companies use block chain and artificial intelligence technology to enhance the scope and depth of big data application. With the support of big data, the value for money assessment of PPP projects will be more accurate, and the correctness and predictability of corporate tax planning will be greatly improved. Digitally transformed governments and intermediary companies provide first-hand data for corporate tax planning. The combination of practical experience and big data by companies will effectively reduce the impact of value-for-money evaluation on corporate tax risks. Smart PPP project companies follow market rules and the commercial laws of the digital economy, and can better guarantee the sustainable operation of PPP projects. The tax planning of PPP projects based on big data must not only reflect the development of the digital economy, but also have sufficient financial resources to advance the project.

\subsection{Improve the VAT Deduction Chain Based on Digital Technology}

The VAT planning of the PPP project company is designed based on the current tax law. During the tax planning process of PPP projects, it was discovered that
China currently has no specific tax policies related to PPP projects. The tax planning of the project company mainly follows common tax laws and regulations, which lacks pertinence. PPP projects involve many fields and large amounts, which are different from the tax issues involved in ordinary goods and services. The Chinese government can use big data technology to conduct a thorough evaluation of PPP projects, analyze taxation issues in the implementation of existing PPP projects, and formulate targeted policies and operating guidelines. In terms of tax planning for PPP projects, the issue of VAT deduction is the main contradiction in the development of enterprises. The particularity of PPP projects makes the existing VAT regulations difficult for project development needs. The sustainable operation of PPP projects should be supported by digital technology. The government allows enterprises to effectively finance based on digital credit, reduce their financing costs, and hedge the problem of VAT deduction. The government allows enterprises to adjust the value-added tax deduction chain, and allows them to expand the scope, link, and exemption of value-added tax for PPP projects.

\subsection{Digital Communication Platform Promotes Effective Communication between Enterprises and Governments}

The continuous operation of PPP projects requires effective communication between the government and enterprises. A reasonable and scientific digital communication platform is conducive to the continuous promotion of partnerships and assists enterprises in effective tax planning. In the intelligent transportation PPP project in Guizhou Province, the project company uses the corporate premises through effective communication to promote the effective operation of the project without additional corporate tax burden. Enterprises and governments establish a normalized digital communication platform. In tax planning activities, under the premise of complying with the law, let relevant stakeholders assist in providing special VAT invoices, which can effectively reduce corporate costs. The digital communication platform makes the implementation of PPP projects and corporate tax planning more effective. The digital platform reduces unnecessary losses and costs in project operations, and helps to balance the fairness and efficiency of public service supply.

\subsection{Big Data Monitoring to Balance Project Port- folio Investment}

Big data monitoring technology improves the financial 
data analysis of PPP project companies. PPP projects have corresponding tax incentives at different stages. Big data monitoring enables tax incentives to be legally and compliant, and improves the effectiveness of corporate tax planning. Companies should make comprehensive use of big data monitoring results. PPP project companies have a reasonable asset-liability ratio and balanced portfolio investment, which will be more conducive to the increase of company value and reduce corporate tax burden. Big data monitoring technology provides an important guarantee for portfolio investment. The upgrade combination of transportation PPP projects and the original assets of the enterprise will bring advantages in tax planning. In terms of VAT, the combination of real estate development projects and PPP projects will bring a multiplier effect. Real estate projects generate a large amount of output tax, and the interest and indirect expenses of the real estate cannot obtain input, which can make up for the shortfall of the PPP project. In terms of corporate income tax, PPP projects are at a loss in the early stage of operation, and real estate projects have a fast turnover, which can solve the problem of mismatch between profit and loss time and projects in terms of corporate income tax.

\subsection{Price Adjustment Mechanism to Deal with the Risk of Time Value}

The core problem of the time value is that changes in time will lead to changes in the amount. In order to deal with the risk of the time value, a reasonable price adjustment mechanism can be formulated, and information based on big data can be provided to alleviate the impact of changes in the amount on tax planning. The construction and operation period of the intelligent transportation PPP project in Guizhou Province has a large span, and the big data generated during operation reflects the time value of money. The PPP model has a long cooperation period, and the consumer price index, labor market index, and project cost are constantly changing. In order to ensure the smooth progress of PPP projects, partners can effectively communicate based on big data changes, and adopt dynamic project price adjustment mechanisms to adapt to changes in the time value of money. The project uses the relevant costs in the first year as a benchmark and establishes a reasonable growth rate. In the process of project operation, refer to the indicators of the National Bureau of Statistics, combine with the big data of economic development, and adjust the original price appropriately to make the tax planning of PPP projects effective and applicable.

\subsection{Improve the Digital Skills of Financial Per- sonnel in PPP Projects}

PPP project companies should make full use of preferential tax policies when making tax planning. In the context of the development of the digital economy, the combination of new infrastructure and PPP projects will have a direct impact on fiscal and taxation policies. When tax planning is involved in a PPP project, it must be adjusted in accordance with the current latest development trends and tax policies, which requires government and corporate staff to continuously improve their digital financial capabilities. Financial personnel with the ability to apply the digital economy are extremely important to the development of the project company. Financial personnel need to continuously improve their digital skills to respond to changes in policies and the digital economic environment. Tax planning requires continuous learning of digital financial knowledge and tax policies. Professional financial personnel use big data technology to legally and rationally conduct tax planning to maximize the company's value. PPP projects require high tax credit ratings, and the digital credit of corporate financial personnel is particularly important. The company combines incentives and supervision mechanisms, and through the big data credit platform, improves the quality of financial personnel and creates good internal conditions for tax planning of PPP projects.

\section{References}

[1] Huang Jiangyu, Cao Fuguo. Research on Poverty Alleviation Effect of the PPP Model in China: Based on the Theory of Sustainable Livelihood[J]. Public Finance Research, 2019(11):102-114.

[2] Akimoto,Fukuo. The Urban Development through Public-Private Partnerships in the United States[J]. Proceedings of the Faculty of Engineering of Tokai University, 1992, 32:119-127.

[3] Coan S M . Uncertain allies: Public-private partnerships in the Boston Compact, 1982-1996.[D]. 1997.

[4] Lehman G , Tregoning I . Public Private Partnerships, Taxation and a Civil Society[J]. Journal of Corporate Citizenship, 2004, 2004(15):77-89.

[5] Macnaughton, Alan. The Theory of Taxation and Public Economics.[J]. Canadian Tax Journal, 2009.

[6] World Bank. Thailand: Country Development Partnership for Competitiveness[J]. World Bank Other Operational Studies, 2010.

[7] Cynthia M, Weed. Congress Considers Eliminating 
The Tax Exemption For Municipal Bonds[J].Practice Group(s):Public Finance, 2011

[8] Armstrong C S , Blouin J L, Larcker D F . The incentives for tax planning $[\mathrm{J}]$. Social ence Electronic Publishing, 2012, 53(1-2):391-411.

[9] Gallardo, Gonzalo. Spain: The tax effect of financing in PPP projects.[J]. International Tax Review, 2012.

[10] Mccann S,Aranda-Mena, G,Edwards P, J. DELIVERING VALUE-FOR-MONEY IN THE OPERATING PHASE OF PUBLIC PRIVATE PARTNERSHIP: INTERVIEW FINDINGS[J]. Public Management Review, 2014, 15(2):91-110.

[11] Shefali Virkar. Information and Communication Technology Platform Design for Public Administration Reform: Tensions and Synergies in Bangalore, India[M].User-Centric Technology Design for Nonprofit and Civic Engagements. Springer International Publishing, 2014.
[12] Novackova, D, Saxunova, D. The Public-Private Partnership Projects Legislation and PPP Project Experience in Slovakia[C].Mic: Managing Sustainable Growth Joint International Conference. University of Primorska, Faculty of Management Koper, 2015.

[13] Joseph A . Infrastructure Projects, Public Project Partnerships and Taxation of Tax-Preferred Entities[J]. Derivatives \& Financial Instruments, 2015, 17(6).

[14] Trynov A, V. Public-Private Investment Partnerships: Efficiency Estimation Methods[J]. èkonomika regiona, 2016, 1(2):602-612.

[15] Nhu C, T,T. Law on corporate income tax incentives for public private partnership projects $[\mathrm{J}]$. 2018.

[16] Shu-Min Y, Ming J, Ai-Zhu S . Tax Policy Optimization of Public and Private Partnership Model[J]. Taxation and Economy, 2019. 